\title{
The Strategies of Developing Communicative Competence of Chinese College Students in the Light of Communication Theory
}

\author{
Yuting Dou \\ School of Foreign Language \\ Shandong Institution of Business and Technology \\ Yantai, Shandong, China
}

\begin{abstract}
This paper firstly introduces the development of the communication theory, and explains the significance and influence of communication theory in second and foreign language teaching. Secondly, it analyzes the problems in the English teaching in the process of cultivating the communicative competence of Chinese college students. Finally, it proposes four strategies to improve college students' English communicative competence in China.
\end{abstract}

Keywords-strategies; communicative competence; Chineses college students; communication theory

\section{INTRODUCTION}

According to (Chinese) COLLEGE ENGLISH TEACHING SYLLABUS FOR NON-ENGLISH MAJORS, language is a tool for human communication, and the final aim of English teaching is to develop student's communicative competence in writing and speaking. In the process of teaching both the linguistic and communicative competences of students should be developed. Therefore, English teachers shall cultivate college students' English communicative competence while helping their students to lay a solid linguistic foundation.

\section{THEORETICAL BASIS}

In the end of 1950s, Chomsky came up with the concept of linguistic competence. He believes that the human brain has Language acquisition device, which could form language rules after absorbing a certain amount of foreign language, thereby human beings could achieve the goal of mastering a foreign language in a creative way. However, this concept ignores human's ability to use language to communicate in a complex social environment.

In 1972, Dell Hymes criticized Chomsky's concept, arguing that the internalization of the linguistic rules cannot help people fully master a language. In his opinion, 'There are rules of use without which the rules of snytax are meaningless.' And then he comes up with the concept of communicative competence, which means if a person wants to use a language to communicate with people properly, he needs both a certain linguistic competence, and the competence of communicative appropriateness. In other words, language learners have to know while they are using a language, they can use it properly and without syntax errors. Therefore, Hymes thinks that the aim of second or foreign language teaching is to help learners to know how to use language properly and correctly in the social communication.

In 1980, On the basis of Hymes' communicative competence, Canale and Swain advanced a communicative competence mode, which divided the communicative competence into the following four parts:

- grammatical competence, the knowledge of lexical items and rules of morphology, syntax, sentencegrammar, semantics and phonology, which is the same as Chomsky's language internalization rules;

- sociocultural competence, the knowledge of the relation of language use to its non-linguistic context, which shares the same idea with Hymes' communicative appropriateness;

- discourse competence, indicating the knowledge of rules governing cohesion and coherence when people use a language;

- strategic competence, which includes verbal and nonverbal communication strategies that may be called into action to compensate for break-downs in communication due to performance variables or to insufficient competence.

This mode has great influence on second and foreign language teaching all over the world. In Communicative Language Teaching, Littlewood points out that the theory of communicative approach has widely opened people's perspectives in second or foreign language teaching. Especially it makes language teachers realize that language teaching is supposed to focus on both language itself and communicative competence.

Since the 1990s, more and more language teachers have carried out the communicative approach in their classes, for such approach sets the cultivation of communicative competence as the goal of second and foreign language teaching. At the same time, communicative language 
teaching has continued to evolve as our understanding of the processes of second language learning has developed.

In China, the government has implemented the expansion enrollment policy in higher education since 1999. An increasing number of students have had the opportunity to study in colleges and universities, but challenges and problems have emerged in language teaching, which are explained as follows.

\section{The Problems WhiLE CUltivating CommunicATIVE COMPETENCE IN ENGLISH ClASSES FOR CHINESE COLLEGE STUDENTS}

In most Chinese colleges and universities, English is set as the most important language in foreign language teaching. And English teaching in Chinese higher education has made great progress in the past ten years. However, there are still some problems, which are as follows:

Firstly, the effectiveness of English teaching is poor because there are so many students in one class. With the rapid growth in college enrollment, English teachers in China have to teach larger classes than ever. There are even more than 100 students in one class, which leads to lower teaching efficiency. The number of the students is so large that it's hard for teachers to employ the communicative approach, which is fit for smaller classes, to cultivate the students' communicative competency. Meanwhile, to develop such competency, students need more practical activities, which has been ignored in many Chinese universities and colleges. All of the above are not helpful to the communicative competence training.

Secondly, the teaching effectiveness is poor because many teachers have been adapting the traditional teaching methods. In their opinion, language teaching should focus on mastery of different grammar. And teachers are the leaders of the class while students are only passively receivers, thus they don't consider it essential that students are supposed to take part in the teaching process actively and voluntarily in class, which goes against the communicative function of language teaching. What's worse, such tedious teaching method and contents cannot meet the needs of students in different levels, which thereby leads to the high rate of absenteeism. As a result, it's even harder to develop their communicative competency.

Thirdly, exam-oriented teaching still exists in China. With the popularity of CET-4 and CET-6 (College English Test Band 4 and Band 6), the two tests are used by most of Chinese universities and colleges as one way to assess students' English level. Moreover, when students hunt for a job after graduation, the certificates of CET-4 and CET- 6 are considered very important to show that they are competent to use English. Indeed, this kind of practice not only stimulates the student's passion of learning English, but also leads to the mode of exam-oriented college teaching, and such teaching spawn lots of students who can get high scores in CET-4and CET-6, but have little communicative competence to use English properly.
Therefore, it is high time to consider how to improve Chinese students' communicative competence in English teaching.

\section{The Strategies to Cultivate Students' COMMUNICATIVE COMPETENCE IN ENGLISH TEACHING IN CHINA}

\section{A. Employ Communicative Approach to Improve Students' Pragmatic Competence}

First of all, during the teaching process, teachers should abandon the traditional teaching method called "cramming", and use communicative approach to highlight the dominant role of students and the leading role of teachers. As Hammer has put it, teachers in class should be the supervisors, judges, organizers, reminders, participants and consultants. Teachers should make efforts to provide students with opportunities to communicate with each other and to show the academic achievements, guide students to achieve their goals, encourage them to express themselves, and exploit their potentiality to strengthen their confidence. As a result, in communicative language teaching, students are expected to take on more responsibility than ever for their own learning, and teachers now play the role of facilitator and monitor.

Secondly, teachers should design class activities elaborately based on communicative theory, and guide students to learn knowledge actively. In order to make English class communicative, teachers should organize various activities while teaching. If teachers guide the students in a right way, students can improve their communicative competence by repetitively applying various communicative ways.

\section{B. Help Students to Acquire Cross-cultural Knowledge and Improve Their Ability of intercultural Communication}

Language is the carrier to culture. If students study one language but cannot understand the social and cultural background of that language, they could not use the language accurately and achieve successful cross-cultural communication. Therefore, when teaching English in China, teachers should help students to know more about the cultural elements of English nations, such as the custom, lifestyle, thinking mode and values etc., which play an important role in English learning. For instance, "Dragon" has quite different symbolic meanings between China and the west. In China, the dragon is a symbol of power, strength, and good luck for people who are worthy of it. With this, the Emperor of China usually used the dragon as a symbol of his imperial power and strength. While in western countries, Dragons have traditionally been a symbol of evil. A typical western dragon can fly and breathe fire. Many legends describe dragons as greedy, keeping hordes of gold and other precious treasure

\section{Help Students to Study Effective Communicative Strategy}

Communicative strategy is also a key to the success of communication. If students are only familiar with the 
language system, they cannot conduct successful communicative activities. They need to study communicative strategy as well. According to the survey, some communicative activities that students would like to do in English classes are as follows: exchanging information, pair work, group discussion, consensus, solving the problem, sketch and pros and cons etc. (Cairen Wang, 1999). These communicative strategies can help Chinese students to bridge the communication gaps caused by linguistic or cultural differences, and these strategies are not only useful for them during school days but also helpful in their future work. Therefore, teachers need to guide students to use these communicative strategies consciously in the real communicative activities.

\section{Utilize E-learning Resources toImprove Students' Communicative Competence}

E-learning resources, such as English learning websites and foreign language instruction websites, Moocs etc., can provide English learners in China a large number of authentic, live and authoritative language materials. And elearning has gained an advantage over traditional classes and traditional methods. Online communication makes it possible for Chinese students to use English creatively, practice it frequently, thus improving their language skills of listening, speaking, reading and writing. On the internet, they can get the access to the specialized tutorial sites to conduct interactive learning and communicate with foreigners. Also, they can chat with each other by email or network groups, or conduct keyboard communication or verbal communication with people who have the same interests. There is no doubt that this kind of instant and wide-range communication method plays an important role in the process of English learning.

\section{CONCLUSION}

In conclusion, in order to develop communicative competence of Chinese students, teachers in Chinese universities and colleges are supposed to apply communicative approach and give up the traditional teaching methods. The emphasis of English teaching should be converted from teaching English, the language itself to helping English learners in Chinese colleges and universities to cultivate their communicative competence. In order to achieve the above goal, the English teachers in China should be student-centered and their teaching emphasis should be put on cultivating communicative competence in a real language environment.

\section{REFERENCES}

[1] W. Littlewood, Communicative Language Teaching. Beijing: Foreign Language Teaching and Research Press , 2002, pp.120-122.

[2] J. Harmer, The Practice of English Language Teaching. London:Longman, 1991, pp.79-82.

[3] https://en.wikipedia.org/wiki/Chinese_dragon.

[4] http://www.draconika.com/cultures/western.php.

[5] Xiaoyong Lu, "The American Five Cs of Foreign Language Study in $21^{\text {st }}$ Century". Foreign Language World, 2001, (5), pp.16-19.
[6] Cairen Wang, A Communication Model for English Language Teaching. Nanning: Guangxi Education Press, 1999, pp.112-115.

[7] The Chinese Ministry of Education, College English Teaching Syllabus for non-English Majors. 2007, pp.12-15.

[8] N. Chomsky, Syntactic Structure. Holland: Holland Hague Morton publishing company, 1957, pp.73-74.

[9] D.H. Hymes, "Two types of linguistic relativity". In Bright, W. Sociolinguistics. The Hague: Mouton, 1966, pp. 114-158.

[10] M. Canale, M. Swain, Theoretical Bases of Communicative Approaches to Second Language Teaching and Testing. Applied Linguistics, 1980, PP1-47. 